\title{
Age Structure of the Workforce in Growing and Declining Industries: Evidence from Hong Kong*
}

Jun Han,

School of Economics, Nankai University, Tianjin, China

Email: jhan@nankai.edu.cn

Wing Suen,

School of Economics \& Finance, University of Hong Kong, Hong Kong

Email :wsuen@econ.hku.hk.

October 2009

\footnotetext{
* We thank Zhigang Li, Hon-Kwong Lui, James Vere, Junsen Zhang, three anonymous referees, and participants in the 2007 APEA, CEA and CES conferences for their comments on this paper. Part of this research is funded by the Hong Kong Institute of Economics and Business Strategy. We gratefully acknowledge its support. Correspondence: Wing Suen, School of Economics \& Finance, University of Hong Kong, Fax: (852) 25481152. Email : wsuen@econ.hku.hk.
} 


\section{Age Structure of the Workforce in Growing and Declining Industries: Evidence from Hong Kong}

October 22, 2009

Abstract. Industry-specific human capital reduces the incentive for older workers to leave declining industries and raises the incentive for younger workers to join growing industries. Using the industry restructuring experience of Hong Kong, we find that a one percent increase in employment share of an industry is associated with a 0.60 year decrease in the average age of its workforce. The relationship is more pronounced among less educated workers, who have less general human capital, and male workers, who are more committed to the labor force, than among well educated workers and female workers.

JEL classification. J10, J23, J24

Keywords. Industry-specific human capital, industry upgrading, sectoral shifts 


\section{Introduction}

A stereotypical worker in the information technology sector is one in his twenties or thirties, while the rural agricultural economy is usually depicted to be populated by older folks. Such stylized characterizations are not a pure fiction: there are indeed large and systematic variations in the age structure of the workforce across different industries. In Hong Kong, the average age of agricultural workers is 15.5 years older than that of workers in the communications industry (49.4 and 33.9 years, respectively). ${ }^{1}$ More interestingly, we find that the age structure of the workforce in an industry is not invariant to changes in the economic environment. Growing industries tend to be populated by younger workers, while older workers stay in declining industries. Take the apparel and textile industry in Hong Kong for example. The industry was a main engine of the early economic growth of Hong Kong (Chen 1979), employing 26.3 percent of the total workforce in 1976. The average worker in that industry then (31.3 years) was 3.8 years younger than the representative worker. With the outsourcing of manufacturing work to mainland China and the restructuring of the Hong Kong economy toward the service industries (see, for example, Suen 1995; Hsieh and Woo 2005), apparels and textiles have steadily lost employment share in the 1980s and 1990s. In 2001 its employment share had shrunk to 3.4 percent. Meanwhile the average age of a textile worker had risen to 42.1 years, which was 3.9 years higher than the economy-wide average. Our paper is an attempt to document and understand these changes in age structure across industries in the context of industrial upgrading in Hong Kong. We believe that our findings are not unique to the local experience.

A key to understanding the relationship between sectoral shifts and variations in age structure across industries is the concept of industry-specific human capital. The

\footnotetext{
${ }^{1}$ Figures reported in this paragraph are based on authors' calculations using records from the Hong Kong population censuses and by-censuses. See Section 2 below for more details of the data.
} 
industry-specific human capital that a worker has accumulated is more productive when the worker stays in the same industry than when he moves to a different industry. Since Derek Neal (1995) introduced this concept to the literature, much of the research has focused on the effect of exogenous job displacement on wages (Carrington 1993; Kletzer 1996; Kim 1998), or on the effect of low-frequency demand shifts on the wage structure (Weinberg 2001; Devereux 2005a, 2005b). But industry-specific human capital also affects young workers and old workers differently because of the different amounts of capital they have accumulated and because of their different incentives to engage in further investments. Our paper emphasizes this differential impact to study the implications for the age structure of growing and declining industries. ${ }^{2}$

It is well known that specific human capital is a significant factor in the determination of labor market turnover (Becker 1964; Parsons 1972). By driving a wedge between what a worker can produce in his current economic sector and what he could otherwise produce in another sector, industry-specific human capital tends to reduce worker mobility across different industries. In their study of job mobility among young men in the United States, Topel and Ward (1992) find that a typical worker holds seven jobs in the first ten years in the labor market, about two-thirds of his career total. We expect young workers, who are relatively mobile, to have accumulated less industry-specific human capital than do old workers, who tend to have stayed in the same industry for a longer period of time. Suppose a negative demand shock hits a certain industry. Then, efficient separation implies that older workers, who have accumulated more industry-specific human capital, are less likely to switch to a different industry lest they lose the value of their human capital investment. Younger workers, on the other hand, are more eager to switch to a different industry

\footnotetext{
${ }^{2}$ See also MacDonald and Weisbach (2004) for a theoretical model of technology-specific human capital investment. They argue that technology change tends to depreciate older workers' skills and turn them into has-beens. The entry of younger workers, who can better grasp new technology, puts a downward pressure on the price of what older workers produce.
} 
with better prospects because of their greater incentive to invest in a new type of industry-specific human capital. The greater incentive for older workers to stay in declining industries and the greater incentive for younger workers to join growing industries predict a negative relationship between the change in employment share of an industry and the average age of its workforce.

We do not claim that industry-specific human capital is the only explanation for the observed relationship between industrial shifts and the age structure of industries. It is possible that preference shifts among the younger cohorts drive systematic changes in industrial composition of the economy. Although we provide a descriptive analysis to argue that the industry upgrading of Hong Kong is likely driven by exogenous demand factors rather than a response to the changing composition of the workforce, a more direct identification strategy, if found, would make our informal argument more convincing. Moreover, part of the observed negative relationship between industry growth and the age of the workforce can be explained by other factors. For example, newly emerging firms with more advanced technolgoy may simply find it unprofitable to hire old workers with obsolete skills. Alternatively, older workers may be less mobile due to other reasons than industry-specific human capital. Until we can directly test the presence of industry-specific skills and link these skills with patterns of worker mobility, our explanation remain merely one of the potential factors behind the observed patterns. In the section on robustness checks, we provide some evidence regarding the timing of the relationship and some estimates that exclude entry-level and near-retirement workers to argue that differential mobility by age is not the entire story. The fact that the negative relationship between employment growth in an industry and the average age of its workforce is more pronounced for educated and male workers is also consistent with our interpretation. Our analysis does not pin down an exclusive factor that explains the observed relationship, but we 
interpret the evidence as suggesting that industry-specific human capital may be the more likely possibility.

While the main objective of this paper is to use the demographic structure of industries to test the implications of industry-specific human capital, studying the age structure of the workforce in different industries has some independent interests. It is well-recognized that workers of different ages have different productivities because of their different experience in the labor market. Moreover, they are not perfect substitutes. Card and Lemieux (2001), for example, use a CES labor aggregator function to estimate the returns to skill for different age cohorts. Their work imply that heterogeneous workers cannot be aggregated simply by converting into efficiency units of labor: the composition of the workforce matters as well as the total quantity. ${ }^{3} \mathrm{Hu}-$ man resources practitioners talk about maintaining an appropriate demographic mix within an organization, often justifying it on the grounds of succession planning and the intergenerational transmission of skills. Feyrer (2007) finds a significant correlation between the age structure of the workforce and aggregate productivity growth across countries. Although there is little research of this connection at an industry level, we expect that demographic structure may have an impact on productivity and productivity growth across industries as well.

To the best of our knowledge, this paper is among the first to explore the relationship between sectoral shifts and the age structure of the workforce across different industries. In a recent contribution, Autor and Dorn (2009) independently propose to use the average age of workers in an occupation to infer occupational opportunities. Like our work, they also resort to occupation-specific human capital to provide the linkage for the negative relationship between occupational growth and occupational age structure.

\footnotetext{
${ }^{3}$ See Suen (2000) for a similar approach applied to estimating the differential impacts of immigration.
} 
The prior literature has mostly focused on the effect of changes in the industrial composition of demand on wages. Neal (1995) uses the Displaced Worker Surveys to show that displaced workers suffer large wage losses from switching industries. He also finds that the probability of switching industries upon displacement is decreasing in pre-displacement tenure and experience. Parent (2000) uses data from the National Longitudinal Survey of Youth and Panel Study of Income Dynamics to show that industry-specific human capital is more important than firm-specific skills in the determination of the wage profile. However, Weinberg (2001) uses the March Current Population Surveys to show that there is no significant relationship between industry-level wages and low-frequency changes in industry demand. He argues that the lack of a significant relationship can arise from the low cost of inter-industry mobility or from wage rigidity. Weinberg's results are disputed by Devereux (2005a). Devereux uses panel data to examine the relationship between long-term changes in industry wages and industry employment. After controlling for the composition of the workforce, he finds a higher positive relationship between wages and employment, which means that the composition of the workforce in these industries has changed: growing industries attract less skilled workers. In another paper, Devereux (2005b) examines the effect of industry growth and decline on wage changes. The main finding is that workers in expanding industries experience much faster wage growth than do other workers, suggesting that the supply of industry-specific human capital is not perfectly elastic.

The issue of cross-industry job mobility has been directly addressed in the literature as well. Kletzer (1996) studies the pattern of sectoral mobility following job displacement. McLaughlin and Bils (2001) find that high-wage industries usually have stronger employment fluctuations, and that positive self-selection can contribute to the cyclical upgrading of the quality of the workforce. Neal (1998) uses a model 
of training choice to show that able workers tend to choose highly specialized jobs, which is an important reason for the negative relationship between wage levels and turnover rates. Devereux and Hart (2006) examine the wage cyclicality of job stayers and job movers, and find that the wage cyclicality of within-company movers is 1015 percent higher than that of stayers, and the wage cyclicality of between-company movers is $30-40$ percent higher than that of stayers. These studies provide analysis on the relationship between wage and mobility, while our present study focuses on the implications of cross-industry mobility for the demographic characteristics of the workforce.

\section{Industrial Restructuring in Hong Kong}

The restructuring of industries in Hong Kong is an often-told story (see, for example, Greenwood 1990; Suen 1995; Berger and Lester 1997). The economic take-off of Hong Kong began in the 1960s and 1970s, when Hong Kong specialized in the manufacture of low-skilled, labor-intensive goods such as textiles, garments, and plastic products. The opening of China in 1978 offered an abundance of new business opportunities and necessitated a relocation of production according to comparative advantage. Manufacturing industries in Hong Kong began a long period of decline as production activities were outsourced to China. Meanwhile outsourcing-related business services such as transport, trade, and finance services grew to become the mainstay of the economy. In the early 1980s, Hong Kong's outward processing trade with China was almost non-existent. By the year 1997, Hong Kong was sending HK\$245 billion and receiving HK\$1087 billion worth of goods to and from China in connection with outward processing trade. To put these numbers in perspective, gross output from all domestic manufacturing establishments had declined from 157 billion to 82 billion (in 1997 Hong Kong Dollars) between 1982 and 1997 (Census and Statistics Department, various years). The shift in the manufacturing base was swift and unmistakable. 
The opening policy in China since 1978 has not led to an abrupt reform, but a gradual economic transition. During this period, the transition from the centrallyplanned to the market-oriented economy has been proceeded in a piecemeal manner. In the early 1990s when Chinese leader Deng Xiaoping conducted a tour to Shenzhen, a special economic zone neighboring to Hong Kong, the economic transition in China accelerated, and the relationship between the mainland and Hong Kong became much closer than ever. We find that the employment change in the textile industry has been more dramatic since the early 1990s, when most of this industry moved north to Guangdong province.

For the purpose of this study, we measure the changing demand for labor in different industries by the changes in their employment shares. As Hsieh and Woo (2005) point out, the Hong Kong experience is particularly interesting because the changes in employment shares are triggered by a largely exogenous event, namely, the opening of China. Thus, changes in employment shares arguably reflect demand factors rather than shifts in preferences or composition of the labor force. Moreover, the pace of sectoral shifts is greater in Hong Kong than in many other economies such as Singapore, Korea, Japan, or the United States (Suen 1995). Thus data from Hong Kong provide large variations in demand changes across industries, which help increase the precision of our estimates.

We calculate employment shares using random sub-samples of the Hong Kong population censuses and by-censuses of 1976, 1981, 1986, 1991, 1996, and 2001. The sample consists of all men and women who were aged 15 or above and who were employed, including employees, employers, the self-employed, and unpaid family workers. ${ }^{4}$ Because the classification of industries has changed over the years, we recode

\footnotetext{
${ }^{4}$ Unpaid family workers refer to individuals who live with the family and do work (not domestic work) as part of the family enterprise in return for food and lodging. They are workers, and are different with home-makers. In any case, such workers represent a very small fraction of the total workforce.
} 
the industry variable in order to keep the consistency and comparability of the definitions. ${ }^{5}$ After dropping individuals whose industry is "unidentifiable or inadequately described" (they make up less than one percent of our sample), we assign workers to 25 different industries and calculate the average characteristics of the workforce in each industry. The result is a panel dataset of 25 industries with six observations for each industry.

Since each industry is observed once every five years, the change in employment share of an industry over successive periods reflects relatively low-frequency changes in demand.

(Insert Table 1 here.)

In Table 1, we show these changes for each five-year period. This table indicates that the changes in the industrial composition of the economy has been quite continuous and uniform over time. If we aggregate these changes into two sub-periods (1976-1991 and 1991-2001) the coefficient of correlation between employment changes in these two sub-periods is 0.83 .

For the purpose of understanding the nature of these low-frequency demand shocks arising from the industry upgrading, we take a closer look at some specific industries that have experienced great changes in employment share:

Agricultural Products. Hong Kong is a small region without much agriculture. In 1976, about 1.6 percent of all workers were engaged in this industry. Urbanization and the rising price of land has almost driven this industry into extinction, with its employment share reduced to 0.13 percent in 2001 .

Manufacturing of Wearing Apparel, Leather and Textile Goods. This is the industry most affected by the economic restructuring process induced by the opening of the Chinese economy. At its peak, the textile industry employed more than a quarter of the Hong Kong workforce. Outsourcing of production into the neighboring Guang-

\footnotetext{
${ }^{5}$ Details of the recoding are shown in Appendix Table 1.
} 
dong province has meant that the Hong Kong operation of textile firms are reduced to a management and control function, with a greatly diminished demand for labor (Suen 1995; Kwok and So 1995). Employment share in this industry was a mere 3.4 percent in 2001. Indeed, such a pattern of industry restructuring and the decline of manufacturing industries in general is not unique to Hong Kong. The other "dragon economies" of Taiwan, Singapore, and South Korea have experienced similar changes (Sung 1995).

Import/Export. We have already discussed the tremendous expansion of outwardprocessing trade in Hong Kong. Economic growth in China further fueled the expansion of trade-related services as Hong Kong served as an important port for the distribution of Chinese manufactured products to the rest of the world. Employment share in this sector increased from 2.8 percent in 1976 to 7.4 percent in 2001.

Real Estate, Rental, Surveying, and Miscellaneous Services. The sustained housing boom in Hong Kong has supported an ever growing fraction of the workforce engaged in this industry. Employment share in this industry has increased from 1.4 percent to 10.7 percent between 1976 and 2001. Again, the increase in employment is clearly due to demand rather than supply factors.

Although we do not have conclusive proof that the changes in industrial structure are driven by demand rather than supply factors, our knowledge about the development and the sources of comparative advantage of the Hong Kong economy leads to the belief that the changes in the industries described above are primarily driven by demand factors. Another corroborating piece of evidence is related to the demand and supply of female workers. In the beginning of our sample period, women workers were concentrated in the labor-intensive light manufacturing industries. In 1976, for example, 44 percent of all women workers were employed in the textile industry. The period 1976-2001 saw a increasing entry of women into the labor force. The 
employment rate of women aged over 15 rose from 40 percent in 1976 to 49 percent in 2001, while that of men fell from 74 percent to 67 percent. Yet the large increase in supply of female workers was associated with a decline of the female-intensive light manufacturing sector, casting doubt on the hypothesis that industry upgrading in Hong Kong was a response to changes in the composition of labor supply.

(Insert Table 2 here.)

Table 2 provides some further characteristics of the data. In the second column, we calculate the average absolute change in employment share for each of the five-year periods. The number in this column multiplied by 25 (25 industries) and divided by 2 (to avoid double counting) is a common measure of the degree of sectoral shifts. For example, the first row of this column suggests that at least 9.4 percent of the working population must have switched industries between 1976 and 1981. Column 2 of Table 2 shows that the magnitude of these shifts are quite sizable. Columns 3 and 4 further indicate that there are significant variations in employment growth and decline across different industries.

In Table 2, we also present summary statistics for the variations in age structure of the workforce across industries. Column 5 shows that there is a general rise in age of the workforce in Hong Kong, with an increase from 35.1 years to 38.2 years

in the twenty-five period under study. This is in line with the aging trend in Hong Kong. However, the average age of the worker also shows significant variations across industries. The difference in average age between the industry with the oldest workers and the industry with the youngest workers is generally larger than ten years. It is to these variations in age structure that we now turn.

\section{Sectoral Shifts and Worker Age Structure}

To take a preliminary look at the data, we plot the average age of workers in 25 industries in 2001 against the 1996-2001 change in employment shares of these industries. 
The fitted line in the figure is a weighted least-squares fit to the data, using 2001 employment shares as weights.

(Insert Figure 1 here.)

Consistent with the prediction based on industry-specific human capital, Figure 1 shows that there is a weak negative relationship between the growth or decline of an industry and the average age of its workers.

(Insert Table 3 here.)

Table 3 presents a more systematic look at the data using regression analysis. The basic equation we estimate is:

$$
A_{i t}=\alpha_{i}+\beta_{t}+\gamma \Delta E_{i t}+\varepsilon_{i t}
$$

where $A_{i t}$ is the average age of workers in industry $i$ at year $t, \Delta E_{i t}$ is the change in employment share of industry $i$ from year $t-5$ to year $t$, and $\alpha_{i}$ and $\beta_{t}$ are the industry and year fixed effects, respectively. Because of the possible correlation in age structure of an industry over time, we report robust standard errors clustered by industries.

In the first column of Table 3, panel A, we present the ordinary least squares estimate of $\gamma$ without industry or year fixed effects. The regression coefficient is -0.56 , indicating that an industry which expands its employment share by one percentage point over a period of five years will have a workforce that is about half a year younger than average. To control for the fact that workers of different age may have comparative advantage in different industries, column (2) includes industry fixed effects in the estimation. We find that these industry fixed effects can account for a substantial fraction of the overall variations in average age in our data. Industries such as "agricultural products" and "marine fishing and fishery products" tend to employ relatively old workers, while "communications" and "banking, finance, and 
investment companies" are dominated by younger workers. In column (3), we estimate the equation with year fixed effects but no industry fixed effects. The coefficients for the year dummy variables confirm the general aging trend of the Hong Kong workforce, but the estimated coefficient for the change in employment shares is not materially different from that in column (1) or (2). Column (4) of Table 3 shows the full specification with both industry and year fixed effects, and column (5) shows the weighted least squares estimate using employment shares as weights. The estimated size of $\gamma$ is very consistent across all these specifications. The "between" and "within" estimates of the effect of employment growth on average age are virtually the same.

Because there is no prior work that estimates the effect of employment change on average worker age, we do not have a reliable benchmark to assess the magnitude of our estimated coefficient of -0.60 in the last column of Table 3. To put this number in perspective, consider the apparels and textiles industry again. This industry experienced a 7.3 point drop in employment share in 1986-1991. Our estimated model suggests that the average age of the industry would be 4.4 years older as a result. In comparison, the estimated year fixed effects of our model only predict that the average age of the workforce would rise by 0.6 year over that period. As another example, consider the real estates industry. Its employment share rose by 2.4 percentage points in 1996-2001, which translates into an estimated 1.4 year decrease in the average age of its workforce. This is more than enough to offset the estimated 1.0 year increase in age due to the general aging of the workforce during that period.

It may be argued that a one percentage point increase in employment share is more important in a small industry than in a large industry. For this reason, we re-estimate our basic regression equation by using $\Delta \log \left(E_{i t}\right)$ instead of $\Delta E_{i t}$ as the independent variable. The results are shown in panel B of Table 3. This panel shows the same basic patterns as panel $\mathrm{A}$, except that the coefficient on $\Delta \log \left(E_{i t}\right)$ in the 
specification of the last column (column 5) is statistically significant at only the ten percent level. Consider a "typical" industry with an employment share of 4 percent. According to the coefficient estimate of -3.53 means that a 25 percent increase (one percentage point increase) in employment share would lead to a -0.88 year decrease in the average age of the industry. This estimate is not very far from the original estimate of -0.60 year presented in panel A.

The theory of industry-specific human capital does not simply predict that the average age of the workforce of an industry increases when the industry experiences a negative shock. The age composition of the workforce is also expected to change. In particular, because the difference in accumulated industry-specific human capital and the difference in incentive to invest are largest between the oldest workers and youngest workers, the differential response to sectoral shifts is also expected to be largest between these two groups of workers.

(Insert Table 4 here.)

In Table 4 , we replace the dependent variable $A_{i t}$ in our basic model equation by the proportion (in percentage) of workers in different age groups. The dependent variable for the six columns of this table correspond to the proportion of workers aged 15-25, 26-35, 36-45, 46-55, and over 55. We find that the proportion of workers in the youngest age group (15-25) has a positive and significant response to an increase in sectoral share. If the employment share of an industry increases by one percentage point, then the proportion of very young workers (aged 15-25) in that industry increases by 1.7 percentage points. The overall fraction of workers in this age group is 24.3 percent, so this increase represents a 7.4 percent rise in share. On the other hand, the proportion of workers in the older age groups (36-45, 46-55, and 55 plus) has a negative response to an increase in sectoral share. For example, if the employment share of an industry rises by one percentage point, then the proportion of its 
workers near retirement (aged over 55) falls by 0.67 percentage points. We do not find any significant effect of demand shifts on the proportion of workers aged 26-35 in the industry. This is consistent with our hypothesis that the differential response to demand shifts is largest among the youngest and oldest workers. Panel B of Table 4 repeats the exercise by replacing $\Delta E_{i t}$ with $\Delta \log \left(E_{i t}\right)$ as the independent variable. The results are largely similar as those shown in panel A.

\section{Robustness Checks}

Because we do not have direct observation on industry-specific skills, our hypothesis that they are responsible for the negative relationship between industry growth and industry age structure remains one of several possible interpretations of the data. There can be other reasons for our finding, such as outliers, age differences in worker mobility, and supply factors (e.g., worker preferences). In this section we provide some robustness checks and additional analysis to show that, while we cannot complete exclude other possibilities, the industry-specific human capital interpretation may be the more plausible explanation.

Outliers. Figures 1 and 2 suggest that the estimated relationship between employment change and average age in an industry may be unduly influenced by a few outliers. We address this issue by excluding observations for which the variable $\Delta E_{i t}$ or $\Delta \log \left(E_{i t}\right)$ lies outside the 5 th and 95 th percentile values. Re-estimating the regression model of Table 3 with these outliers removed (the number of observations is reduced from 125 to 113 ) produces regression coefficients of -0.836 (s.e. $=0.662$, robust standard error) and -6.339 (s.e. $=1.910$ ), respectively, corresponding to column 5 in Panel $\mathrm{A}$ and $\mathrm{B}$ of Table 3. If we exclude observations for which $\Delta E_{i t}$ or $\Delta \log \left(E_{i t}\right)$ lies outside the 10 th and 90 th percentile values (reducing the number of observations from 125 to 101 ), the coefficients become -1.316 (s.e. $=0.957$ ) and $-6.873($ s.e. $=2.972)$, respectively. These estimates suggest that our main results are 
not simply driven by the presence of a few influential observations.

Entry-Level Adjustment and Retirement. An alternative explanation for the observed negative correlation between employment growth of an industry and average age of its workforce is that entry and exit of labor occurs at different points of the life cycle. Growing industries have more open positions to fill and younger workers are more likely to be applying to these jobs, if for no other reason than that younger workers are more likely to have just finished school. On the other hand, declining industries shrink via a combination of attrition through retirement, hiring freezes, and layoffs. To the extent that employers in declining industries encourage early retirement or lay off the senior workers, this will contribute to a younger workforce. But to the extent that employers stop hiring young workers or lay off their recent hires, this can contribute to an older workforce. In order to disentangle these effects of entry and exit from the effects of industry-specific human capital on job turnover, we can focus on workers who are not near schooling-leaving age or near retirement age.

(Insert Table 5 here.)

In Table 5, panel A, we re-estimate our basic regression after excluding workers aged 15-24 and workers aged 56 or above. The dependent variable $A_{i t}$ is the average age of the workforce among workers aged 25-55 (but the independent variable $\Delta E_{i t}$ is still calculated by including all workers). In the weighted least squares specification with both industry effects and year effects (column 5), the estimated coefficient on $\Delta E_{i t}$ is -0.23 . This is smaller than the earlier estimate of -0.60 , suggesting that entry-level adjustment and retirement are indeed conducive to the negative relationship between age structure and employment share. Nevertheless, the negative coefficient of -0.23 estimated for workers aged $25-55$ also suggests that there is some differential job-switching induced by different degrees of industry-specific human cap- 
ital between the young and old. In panel B of Table 5, we further restrict the focus to workers aged between 30 and 50. As is to be expected, the coefficient estimates are smaller than those shown in panel A. This is consistent with our findings in Table 4 that the youngest and oldest workers tend to be most affected by the industry upgrading. In sum, we find that entry-level adjustment and retirement also contribute to the negative relationship between age structure and employment, but job turnover related to the industry-specific human capital remains an important part of the observed negative correlation.

Identification Issues. In estimating the relationship between the change in employment share of an industry and the age structure of its workforce, our maintained assumption is that changes in employment share reflect low-frequency sectoral shifts in demand. We have justified this maintained assumption in Section 2 by appealing to a qualitative description of selected sectors of the Hong Kong economy. We argue that much of the employment changes in these sectors can be traced to clearly identifiable demand forces that are unrelated to worker preferences or worker age structure. In this subsection, we supplement our main argument with some quantitative evidence.

If industry growth and decline reflect a shift in worker preferences toward working in particular sectors (e.g., young workers brought up in urban lifestyles might dislike agricultural work) rather than demand-side factors, one would expect that declining industries are ones that face labor shortage while growing industries have a surplus of job applicants. Suen (1995), however, shows that growing industries tend to experience higher wage growth. ${ }^{6}$ Our data also contain information on the industry of the previous job held by those unemployed in the years 1976, 1981, and 1986. We calculate the industry-specific unemployment rate as the number of unemployed from an industry divided by the sum of employed and unemployed from the same industry. (Insert Figure 2 here.)

\footnotetext{
${ }^{6}$ This is consistent with Devereux's $(2005 \mathrm{a}, 2005 \mathrm{~b})$ findings for the United States.
} 
Figure 2 depicts the relationship between the employment growth of an industry from 1981 to 1986 and the industry-specific unemployment rate in 1986. The fitted least squares line slopes downward, with an estimated slope of $-0.68($ s.e. $=0.24){ }^{7}$ Since the measured industry-specific unemployment rate probably responds more to high-frequency changes in demand rather than to five-year shifts in employment shares, we do not expect the relationship between these variables to be very tight. At the very least, Figure 2 does not lend support to the hypothesis that changes in employment shares are driven by supply factors.

Another possible objection to the basic model we estimate is the reverse causality problem. One might conceivably argue, for example, that younger workers are more creative than older workers are, and therefore industries with more young workers grow faster than do other industries. We test this hypothesis by looking at the relative wages of young and old workers across industries. If younger workers are indeed more creative (and therefore more valuable) in growing industries, we would expect that their wages relative to older workers would be higher in these industries. In addition, the rising demand in growing industries can have a positive premium on wages of younger workers. Integrating these two effects would cause the premium to be much higher for younger workers in expanding industries. Based on the findings from Table 4, we measure the relative wage of young workers as the logarithm of the average wage of workers aged 15-35 minus that of workers aged over 35 .

(Insert Table 6 here.)

Table 6 presents the regression results. In the first two columns, the dependent variable is the relative wage of young workers in industry $i$ at year $t$. Both the weighted and unweighted estimates of the coefficient for $\Delta E_{i t}$ are negative but not significant at conventional levels. In columns (3) and (4), the dependent variable is

\footnotetext{
${ }^{7}$ The estimated slope is -0.89 (s.e. $=0.44$ ) when observations are weighted by their employment shares. The relationship between employment growth in 1976-1981 and industry-specific unemployment rate in 1981 is similar.
} 
the relative wage of young workers in industry $i$ at year $t$ with education level $j .^{8}$ When we control for the education premium and changes in education premium over time, the estimated coefficients for $\Delta E_{i t}$ are positive but statistically insignificant. In all four columns of the table, the magnitude of the effect of change in employment share on the relative wage of young workers is trivial. Given the analysis that there are two effects which would increase the wage premium for younger workers in expanding industries, the insignificant result can not verify the reverse causality story plausible.

Timing Issues. In the previous section, we focus on using employment change from year $t-5$ to year $t$ to explain the age structure in year $t$. To the extent that individuals can forecast changes in industry structure of the economy, the same forces that cause young workers to choose growing industries and old workers to stay in declining industries will produce a negative relationship between future changes in employment shares and current age structure across industries. Recall that there is a high degree of persistence in the process of industrial restructuring in Hong Kong. Therefore, it is not unreasonable to believe that workers at least have some ability to predict low-frequency changes in demand across different sectors.

(Insert Table 7 here.)

Table 7, column (1), presents the estimation result of our basic equation using $\Delta E_{i t+5}$ instead of $\Delta E_{i t}$ as the explanatory variable. Even though the timing of the explanatory variable and the sample period are different, the estimated value of $\gamma$ is not materially affected. The estimated $\gamma$ is -0.59 under this specification, compared to the estimate of -0.60 in the previous section. In column (2), we include both $\Delta E_{i t}$ and $\Delta E_{i t+5}$ in the regression. The coefficient on the lagged change $\Delta E_{i t}$ remains negative and significant, while the coefficient on lead change $\Delta E_{i t+5}$ is negative but

\footnotetext{
${ }^{8}$ We classify workers into three education groups: primary and below, secondary, and college and above. The sample size is not three times as large as the sample size shown in columns (1) and (2), because some of the cells are too small to give a meaningful measure of the relative wage of young workers.
} 
not significant. We also experiment with longer term demand changes by using $E_{i t+5}-$ $E_{i t-5}$ to measure the change in employment share. As can be seen in column (3) of Table 7, the estimated response of average age in an industry to five-year changes in employment share or to ten-year changes share is quite similar.

Following a period of expansion, an industry will consist of many new workers who have come from other industries. If workers who have moved are predominantly young, then the average age of the workforce in an expanding industry will fall, with or without industry-specific human capital. We show in Table 7 that the workforce tends to be younger even for industries which are expected to expand (but have not experienced the actual expansion yet). Since such industries do not necessarily employ a disproportionate fraction of workers who have recently moved, our finding cannot be completely attributable to the selection effect due to differential mobility by age. We interpret our result as suggesting that, in order to preserve industry-specific human capital, younger workers have greater incentive to pursue their careers in industries which are expected to expand than industries which are expected to decline.

Columns (4) to (6) of Table 7 replicate the analysis using employment growth rates instead of changes in employment shares. We see that the estimated coefficients are all negative, though most are only significant at the ten percent level. The magnitudes of the estimated effect using the level specification and the log specification are comparable. For example, if an industry increases its employment share from four percent to five percent over a period of ten years, the model in column (6) suggests that average age in that industry will fall by 0.68 year.

Analysis by Sub-groups. Sectoral shifts in demand may affect the average age of workers in an industry through a composition effect. If growing industries also demand more educated workers or more female workers, and if educated workers or female workers tend to be relatively young, then the composition effect would reduce 
the average age of the workforce in growing industries. One way of controlling for these effects is to look at changes in average age for workers within a definite education of gender group.

(Insert Table 8 here.)

For example, in the first row of Table 8, we estimate the average age of workers with no schooling in industry $i$ at year $t$ as a function of $\Delta E_{i t}$ and industry and year dummies. The estimated coefficient is negative but statistically insignificant. Comparing the estimation across different education groups, we find that less educated workers tend to be more responsive to industry growth and decline than are more educated workers. A possible reason for this observation is that industry-specific human capital may be relatively more important than general human capital for the less educated workers. Table 8 also shows that both the average age of male workers and the average age of female workers in an industry fall as the industry expands its employment share in the economy. In the case of female workers, however, the estimated response is not statistically significant. It is possible that the intermittent pattern of labor force participation reduces the importance of industry-specific human capital for female workers.

Industry-Occupation Mix. The process of industry restructuring is often associated with within-industry changes in the structure of occupations. ${ }^{9}$ In practice, the distinction between industry-specific human capital and occupation-specific human capital may not be very clear. We therefore supplement our analysis by investigating the effect of changes in occupation structure as well as changes in industry structure.

To this end, we recode the occupation variable into 26 two-digit groups so as to maintain consistency across census years. We then regress the average age of workers in an occupation on the change in employment share of that occupation. The result

\footnotetext{
${ }^{9}$ Evans (1999) analyzes the cyclical structure of occupational upgrading and downgrading.
} 
is displayed in column (1) of Table 9.

(Insert Table 9 here.)

We find that the demographic response to occupation demand shocks is still significantly negative, with an estimated coefficient of -0.22 , though it is smaller in magnitude than the response of worker average age to industry demand shocks. In columns (2) through (6) of the table, we construct industry-occupation cells and use the average age of workers in each industry-occupation cell as the dependent variable. Many of these cells are quite small if we maintain the 25 industries by 26 occupations classification. So we change the level of aggregation to one-digit level, resulting in 56 industry-occupation cells. ${ }^{10}$ For columns (2) and (3), we use the change in employment share of each industry-occupation cell as the independent variable. The difference between them lies in the different ways of controlling for fixed effects. Both specifications produce similar results: a one percentage point increase in cell employment share is associated with a 0.17 year fall in the average age of workers in that cell. We also experimented with using changes in occupation share (column 4), changes in industry share (column 5), and a combination of these two variables (column 6) as regressors. Our finding of a negative relationship between average worker age and employment share is robust to these alternative specifications.

\section{Conclusion}

This paper analyzes the response of industry demographic structure to industry upgrading in Hong Kong. In the period under study manufacturing industries have declined sharply in employment and production, while services industries have re-

\footnotetext{
${ }^{10}$ Although we have eight one-digit industries and ten one-digit occupations, the number of industry-occupation cells is not 80. Some occupations do not appear in all industries. For example, the occupation "market-oriented agricultural and fishery workers" only appears in agriculture-related industries. There are also some industry-occupation cells with very small cell size. The number of individuals in the data files working in the "agricultural products" industry with the occupation of "managers or professionals," for instance, is often below 10. We record the employment share of an industry-occupation cell in any one year as "missing" if there are less than 30 individuals in that cell.
} 
placed manufacturing as the dominant sector of the economy. We find that these long-term demand shifts are associated with predictable effects on the average age of workers in different industries. Expanding industries tend to attract relatively young workers, while declining industries tend to be filled with older workers. The results show that the average age of workers in an industry is about 0.60 year younger when the employment share of that industry increases by one percentage point. We also find that the youngest and oldest workers are most responsive to changes in employment shares of their industries, whereas the proportion of workers aged 26-35 is not significantly associated with these demand shifts. Furthermore, less educated workers and male workers tend to be more responsive to demand shifts compared to more educated workers (who possess more general human capital) and female workers (who have lower attachment to the labor force). These broad patterns are generally consistent with the effects of industry-specific human capital on workers' mobility and entry decisions.

There exist several possible reasons for the finding, but our analyses seem to suggest that industry specific human capital may be the more likely possibility. One important limitation of this paper is that our data do not contain information on the industry tenure. As a result we do not have direct evidence on how industryspecific human capital affects labor mobility decisions. We can only establish an indirect linkage through the relationship between industry growth and the resulting age structure of the workforce. Our conclusions are subject to criticism regarding the direction of causality and alternative explanations such as the differential effects of age on labor mobility. We argue in Section 2 and in Section 4 that the industry upgrading of Hong Kong is likely driven by exogenous demand factors rather than a response to the changing composition of the workforce. A more direct identification strategy, if found, would make our informal argument more convincing. We also agree that 
part of the observed negative relationship between industry growth and the age of the workforce can be explained by the differential mobility of young and old workers. However, the evidence presented in Section 4 regarding timing of the relationship and the fact that the negative relationship is more pronounced for educated and male workers suggests that differential mobility by age is not the entire story. The broad pattern of our data suggests that forces due to industry-specific human capital are at work. 


\section{References}

[1] Autor D and Dorn D (2009) The Job is 'Getting Old': Measuring Changes in Job Opportunities using Occupational Age Structure. American Economic Review 99 (2): $45-51$.

[2] Becker GS (1964) Human Capital. Cambridge: National Bureau of Economic Research.

[3] Berger S, Lester RK (1997) Made by Hong Kong. Hong Kong: Oxford University Press.

[4] Berman E, Bound J and Griliches Z (1994) Changes in the Demand for Skilled Labor within U.S. Manufacturing: Evidence from the Annual Survey of Manufacturers. Quarterly Journal of Economics 109 (2): 367-397.

[5] Card D, Lemieux T (2001) Can Falling Supply Explain the Rising Return to College for Younger Men? A Cohort Analysis. Quarterly Journal of Economics 116 (2): 705-746.

[6] Carrington W (1993) Wage Losses for Displaced Workers: Is It Really the Firm That Matters? Journal of Human Resources 28: 435-462.

[7] Census and Statistics Department. Various years. Hong Kong Annual Digest of Statistics. Hong Kong: Census and Statistics Department.

[8] Chen EKY (1979) Hyper-Growth in Asian Economies. New York: Holmes Meier Publishers.

[9] Devereux PJ (2005a) Do Employers Provide Insurance against Low Frequency Shocks? Industry Employment and Industry Wages. Journal of Labor Economics 23 (2): 313-340. 
[10] Devereux PJ (2005b) Effects of Industry Growth and Decline on Gender and Education Wage Gaps in the 1980s. Industrial and Labor Relations Review 58 (4): $552-570$.

[11] Devereux PJ, Hart RA (2006) Real Wage Cyclicality of Job Stayers, WithinCompany Job Movers, and Between-Company Job Movers. Industrial and Labor Relations Review 60 (1): 105-119.

[12] Evans P (1999) Occupational Downgrading and Upgrading in Britain. Economica 66: $79-96$.

[13] Feyrer J (2007) Demographics and Productivity. Review of Economics and Statistics 89 (1): 100-109.

[14] Greenwood J (1990) The Changing Structure and Competitiveness of the Hong Kong Economy. Asian Monetary Monitor 14: 21-31.

[15] Hsieh CT and Woo KT (2005) The Impact of Outsourcing to China on Hong Kong's Labor Market. American Economic Review 95 (5): 1673-1687.

[16] Kim DIl (1998) Reinterpreting Industry Premiums: Match-Specific Productivity. Journal of Labor Economics 16 (3): 479-504.

[17] Kletzer LG (1996) The Role of Sector-Specific Skills in Post-Displacement Earnings. Industrial Relations 35 (4): 473-490.

[18] Kwok R, So A (1995) The Hong Kong-Guangdong Link: Partnership in Flux. Armonk: M.E. Sharpe.

[19] MacDonald G, Weisbach MS (2004) The Economics of Has-beens. Journal of Political Economy 112 (1, part 2): S289-S310. 
[20] McLaughlin KJ, Bils M (2001) Interindustry Mobility and the Cyclical Upgrading of Labor. Journal of Labor Economics 19 (1): 94-135.

[21] Neal D (1995) Industry-Specific Human Capital: Evidence from Displaced Workers. Journal of Labor Economics 13 (4): 653-677.

[22] Neal D (1998) The Link between Ability and Specialization. Journal of Human Resources 33 (1): 173-200.

[23] Parent D (2000) Industry-Specific Human Capital and the Wage Profile: Evidence from the NLSY and the PSID. Journal of Labor Economics 18 (2): 306323.

[24] Parsons DO (1972) Specific Human Capital: An Application to Quit Rates and Layoff Rates. Journal of Political Economy 80: 1120-1143.

[25] Suen W (1995) Sectoral Shifts Impact on Hong Kong Workers. Journal of International Trade and Economic Development 4 (2): 135-152.

[26] Suen W (2000) Estimating the Effects of Immigration in One City. Journal of Population Economics 13 (1): 99-112.

[27] Sung YW (1995) The Fifth Dragon: The Emergence of the Pearl River Delta. Singapore: Addison Wesley.

[28] Topel RH, Ward MP (1992) Job Mobility and the Careers of Young Men. Quarterly Journal of Economics 107 (2): 439-479.

[29] Weinberg BA (2001) Long-Term Wage Fluctuations with Industry-Specific Human Capital. Journal of Labor Economics 19 (1): 231-264. 
Table 1. Changes in Industry Employment Shares

\begin{tabular}{|c|c|c|c|c|c|c|c|}
\hline Industry & $\begin{array}{c}\text { Employment } \\
\text { Share } 1976 \\
(\%)\end{array}$ & $\begin{array}{c}\text { Change in } \\
\text { Employment } \\
\text { Share 1976- } \\
1981(\%)\end{array}$ & $\begin{array}{c}\text { Change in } \\
\text { Employment } \\
\text { Share 1981- } \\
1986(\%)\end{array}$ & $\begin{array}{c}\text { Change in } \\
\text { Employment } \\
\text { Share 1986- } \\
1991(\%)\end{array}$ & $\begin{array}{c}\text { Change in } \\
\text { Employment } \\
\text { Share 1991- } \\
1996(\%)\end{array}$ & $\begin{array}{c}\text { Change in } \\
\text { Employment } \\
\text { Share 1996- } \\
2001(\%)\end{array}$ & $\begin{array}{c}\text { Change in } \\
\text { Employment } \\
\text { Share 1976- } \\
2001(\%)\end{array}$ \\
\hline Agricultural Products & 1.55 & -0.48 & 0.63 & -1.14 & -0.35 & -0.08 & -1.42 \\
\hline Marine Fishing \& Fishery Products & 0.26 & -0.02 & -0.11 & 0.32 & -0.10 & -0.10 & 0.00 \\
\hline Mining and Quarrying & 0.06 & 0.01 & -0.04 & 0.00 & -0.01 & -0.01 & -0.05 \\
\hline Food, Beverage and Tobacco Industries & 1.29 & 0.04 & -0.23 & -0.10 & -0.12 & -0.20 & -0.61 \\
\hline $\begin{array}{l}\text { Manufacturing of Wearing Apparel, Leather and } \\
\text { Textile Goods }\end{array}$ & 26.27 & -3.99 & -2.99 & -7.33 & -5.69 & -2.85 & -22.85 \\
\hline $\begin{array}{l}\text { Manufacturing of Wood and Cork Products, } \\
\text { Furniture and Fixtures }\end{array}$ & 1.25 & 0.09 & -0.46 & -0.39 & -0.26 & -0.06 & -1.08 \\
\hline $\begin{array}{l}\text { Manufacturing of Paper and Paper Products, } \\
\text { Printing, Publishing }\end{array}$ & 2.13 & -0.16 & 0.08 & 0.00 & 0.01 & -0.03 & -0.10 \\
\hline $\begin{array}{l}\text { Manufacturing of Chemical Products, Coal and } \\
\text { Plastic }\end{array}$ & 2.26 & -0.09 & -0.35 & 3.09 & -1.93 & -0.96 & -0.23 \\
\hline Manufacturing of Basic Metal Industries & 4.56 & 0.85 & -1.10 & -1.80 & -2.05 & -0.26 & -4.35 \\
\hline $\begin{array}{l}\text { Manufacturing of Machinery, Equipments, Parts } \\
\text { and Components }\end{array}$ & 6.71 & 0.85 & -1.03 & -1.20 & 0.68 & -2.09 & -2.80 \\
\hline Electricity, Gas and Water & 0.57 & 0.04 & 0.07 & -0.01 & 0.00 & -0.14 & -0.05 \\
\hline Construction & 5.96 & 1.90 & -1.63 & 0.64 & 1.23 & -0.60 & 1.55 \\
\hline Wholesale & 0.77 & 0.70 & 0.68 & -0.04 & 0.10 & -0.04 & 1.40 \\
\hline Retail & 11.56 & -3.44 & 0.57 & -0.52 & 0.54 & 0.07 & -2.79 \\
\hline Import / Export & 2.77 & 0.49 & 0.65 & 0.53 & 1.52 & 1.47 & 4.66 \\
\hline Restaurants and Hotels & 5.84 & 1.10 & 0.68 & 0.44 & -0.11 & 0.02 & 2.12 \\
\hline
\end{tabular}




\begin{tabular}{|c|c|c|c|c|c|c|c|}
\hline Transport and Supporting Services & 6.61 & -0.31 & 0.59 & 1.41 & 1.01 & -0.12 & 2.57 \\
\hline Storage & 0.28 & 0.02 & -0.06 & 0.05 & -0.09 & -0.01 & -0.09 \\
\hline Communications & 0.61 & 0.14 & 0.11 & 0.28 & 0.33 & 0.31 & 1.17 \\
\hline Banking, Finance, and Investment Companies & 2.00 & 0.83 & 0.06 & 0.80 & 0.59 & -0.01 & 2.28 \\
\hline Insurance & 0.23 & 0.09 & 0.10 & 0.39 & 0.20 & 0.25 & 1.03 \\
\hline $\begin{array}{l}\text { Real Estate, Rental, Surveying, and } \\
\text { Miscellaneous Services }\end{array}$ & 1.41 & 0.43 & 1.29 & 2.93 & 2.19 & 2.40 & 9.24 \\
\hline $\begin{array}{l}\text { Public, Sanitary, Education, Research, Health, } \\
\text { Business, and Related Services }\end{array}$ & 8.63 & 1.49 & 2.36 & -0.54 & 1.11 & 1.69 & 6.12 \\
\hline Motion Pictures and Entertainment Services & 0.89 & 0.37 & 0.23 & 0.13 & 0.21 & 0.00 & 0.94 \\
\hline $\begin{array}{l}\text { Repair Services, Laundry and Miscellaneous } \\
\text { Personal Services }\end{array}$ & 5.52 & -0.97 & -0.11 & 2.09 & 0.97 & 1.33 & 3.31 \\
\hline
\end{tabular}




\section{Table 2. Data Characteristics of 25 Industries}

\begin{tabular}{|c|c|c|c|c|c|c|}
\hline Year & \multicolumn{2}{|c|}{ Change in Employment Share (\%) } & \multicolumn{3}{c|}{ Average Age } \\
\hline & $\begin{array}{c}\text { Average of } \\
\text { absolute value }\end{array}$ & Maximum & Minimum & $\begin{array}{c}\text { Overall } \\
\text { Average* }\end{array}$ & Maximum & Minimum \\
\hline 1976 & N/A & N/A & N/A & 35.17 & 47.41 & 27.35 \\
\hline 1981 & 0.76 & 1.90 & -3.99 & 35.06 & 48.45 & 28.72 \\
\hline 1986 & 0.65 & 2.36 & -2.99 & 35.61 & 41.50 & 30.72 \\
\hline 1991 & 1.05 & 3.09 & -7.33 & 36.33 & 47.82 & 31.13 \\
\hline 1996 & 0.86 & 2.19 & -5.69 & 37.21 & 50.57 & 32.87 \\
\hline 2001 & 0.60 & 2.40 & -2.85 & 38.24 & 49.37 & 33.86 \\
\hline
\end{tabular}

Note: *The overall average age is calculated as the weighted average of industry ages, with the weights based on the employment share of each industry. 
Table 3. Sectoral Shifts and Worker Average Age (Dependent variable: the average age of workers in industry $i$ at year $t$ )

Panel A: Independent Variable is $\Delta \mathrm{E}_{\mathrm{i}}$
(1)
(2)
(3)
(4)
(5)

\begin{tabular}{lccccc}
$\Delta \mathrm{E}_{\mathrm{i} \mathrm{t}}$ & $-0.564^{* *}$ & $-0.578^{*}$ & $-0.564^{* *}$ & $-0.578^{*}$ & $-0.600^{* *}$ \\
Industry & $(0.244)$ & $(0.299)$ & $(0.253)$ & $(0.331)$ & $(0.265)$ \\
Year & No & Yes & No & Yes & Yes \\
Weight & No & No & Yes & Yes & Yes \\
\hline
\end{tabular}

Panel B: Independent Variable is $\Delta \log \left(\mathbf{E}_{\mathrm{i}}\right)$
(1)
(2)
(3)
(4)
(5)

\begin{tabular}{lccccc}
$\Delta \log \left(\mathrm{E}_{\mathrm{i}}\right)$ & $-5.448 * * *$ & $-3.575^{* * *}$ & $-5.003 * * *$ & $-2.465 * * *$ & $-3.528 *$ \\
& $(1.321)$ & $(0.773)$ & $(1.397)$ & $(0.847)$ & $(1.883)$ \\
Industry & No & Yes & No & Yes & Yes \\
Year & No & No & Yes & Yes & Yes \\
Weight & No & No & No & No & Yes \\
\hline
\end{tabular}

Note: Robust standard errors in parentheses. The significance levels: * significant at $10 \%$; ** significant at $5 \% ; * * *$ significant at $1 \%$. 
Table 4. Sectoral Shifts and Worker Age Composition (Dependent variable: share of each age group in industry $i$ at year $t$, in percentage)

Panel A: Independent Variable is $\Delta \mathbf{E}_{\mathrm{it}}$

(1)

(2)

(3)

(4)

(6)

\begin{tabular}{cccccc} 
& Age 15-25 & Age 26-35 & Age 36-45 & Age 46-55 & Age > 55 \\
$\Delta \mathrm{E}_{\mathrm{i} \mathrm{t}}$ & $1.768 * * *$ & 0.035 & $-0.344 * *$ & $-0.789 *$ & $-0.670^{*}$ \\
& $(0.607)$ & $(0.357)$ & $(0.149)$ & $(0.401)$ & $(0.386)$ \\
\hline
\end{tabular}

Panel B: Independent Variable is $\Delta \log \left(\mathbf{E}_{i}\right)$
(1)
(2)
(3)
(4)
(6)

Age 15-25 Age 26-35 Age 36-45 Age 46-55 Age $>55$

$\begin{array}{llllll}\Delta \log \left(\mathrm{E}_{\mathrm{i}}\right) & 9.815^{* *} & 0.523 & -1.623 & -4.066 & -4.649^{*} \\ & (4.230) & (2.540) & (0.960) & (2.832) & (2.682)\end{array}$

Note: We have used weighted least squares with weights based on the industry employment share. In addition, we have also controlled for industry and year fixed effects. Robust standard errors are in parentheses. The significance levels: * significant at $10 \% ;{ }^{* *}$ significant at $5 \% ;{ }^{* *}$ significant at $1 \%$. 
Table 5. Sectoral Shifts and Worker Average Age for age25-55 and 30-50 (Dependent variable: the average age of workers in industry $i$ at year $t$; Independent variable: $\Delta E_{i t}$ )

\section{Panel A: Workers Aged 25-55}

(3)

(4)

\begin{tabular}{|c|c|c|c|c|c|}
\hline \multirow[t]{2}{*}{$\Delta \mathrm{E}_{\mathrm{i} \mathrm{t}}$} & $-0.450 * *$ & -0.246 & $-0.448 * *$ & -0.241 & $-0.230 *$ \\
\hline & $(0.171)$ & $(0.150)$ & $(0.174)$ & $(0.161)$ & $(0.125)$ \\
\hline Industry & No & Yes & No & Yes & Yes \\
\hline Year & No & No & Yes & Yes & Yes \\
\hline Weight & No & No & No & No & Yes \\
\hline \multicolumn{6}{|c|}{ Panel B: Workers Aged 30-50 } \\
\hline \multirow{3}{*}{$\Delta \mathrm{E}_{\mathrm{it}}$} & (1) & (2) & (3) & (4) & $(5)$ \\
\hline & $-0.242 * *$ & -0.108 & $-0.239 * * *$ & -0.102 & -0.097 \\
\hline & $(0.089)$ & $(0.095)$ & $(0.082)$ & $(0.080)$ & $(0.062)$ \\
\hline Industry & No & Yes & No & Yes & Yes \\
\hline Year & No & No & Yes & Yes & Yes \\
\hline Weight & No & No & No & No & Yes \\
\hline
\end{tabular}

Note: Robust standard errors in parentheses. The significance levels: * significant at $10 \%$; ** significant at $5 \%$; ** significant at $1 \%$. 
Table 6. Sectoral Shifts and the Relative Wage of Young Workers (Dependent variable: logarithm of the wage of workers aged 15-35 minus that of workers aged over 35 from industry $i$ at year $t)$

\begin{tabular}{lcccc}
\hline & $(1)$ & $(2)$ & $(3)$ & $(4)$ \\
$\Delta$ Ei t & -0.003 & -0.001 & 0.007 & 0.002 \\
& $(0.013)$ & $(0.007)$ & $(0.008)$ & $(0.004)$ \\
Industry effect & Yes & Yes & Yes & Yes \\
Year effect & Yes & Yes & No & No \\
Interactions between year and education & No & No & Yes & Yes \\
weight & No & Yes & No & Yes \\
Observations & 125 & 125 & 370 & 370 \\
R-squared & 0.66 & 0.80 & 0.44 & 0.84 \\
\hline
\end{tabular}

Note: Robust standard errors are in parentheses. Weights are based on industry employment shares. The significance levels: * significant at $10 \% ; * *$ significant at $5 \% ; * * *$ significant at $1 \%$. 
Table 7. Timing and Growth Rates (Dependent variable: average age of workers in industry $i$ at year $t$ )

\begin{tabular}{|c|c|c|c|c|c|c|}
\hline & (1) & (2) & (3) & (4) & (5) & (6) \\
\hline$\Delta \mathrm{E}_{\mathrm{it}+5}$ & $\begin{array}{c}-0.590 * * \\
(0.278)\end{array}$ & $\begin{array}{l}-0.367 \\
(0.224)\end{array}$ & & & & \\
\hline$\Delta \mathrm{E}_{\mathrm{i} \mathrm{t}}$ & & $\begin{array}{c}-0.658 * * \\
(0.264)\end{array}$ & & & & \\
\hline$E_{i t}-E_{i t-10}$ & & & $\begin{array}{c}-0.362 * * \\
(0.153)\end{array}$ & & & \\
\hline$\Delta \log \left(\mathrm{E}_{\mathrm{it}}\right)$ & & & & & $\begin{array}{l}-3.054 * \\
(1.573)\end{array}$ & \\
\hline$\Delta \log \left(\mathrm{E}_{\mathrm{i} t+5}\right)$ & & & & $\begin{array}{l}-3.809 * \\
(1.922)\end{array}$ & $\begin{array}{l}-2.301 * \\
(1.305)\end{array}$ & \\
\hline $\log \left(E_{i t+5}\right)-\log \left(E_{i t-5}\right)$ & & & & & & $\begin{array}{c}-2.718 * * \\
(1.243)\end{array}$ \\
\hline Observations & 125 & 100 & 100 & 125 & 100 & 100 \\
\hline R-squared & 0.68 & 0.75 & 0.83 & 0.7 & 0.75 & 0.75 \\
\hline
\end{tabular}

Note: We have used weighted least squares with weights based on the industry employment share. In addition, we have also controlled for industry and year fixed effects. Robust standard errors are in parentheses. The significance levels: * significant at $10 \%$; * significant at 5\%; $* *$ significant at $1 \%$. 
Table 8. Analysis by Sub-groups (Dependent variable: average age of workers in each sub-group in industry $i$ at year $t$ )

\begin{tabular}{|c|c|c|c|}
\hline & & \multicolumn{2}{|c|}{$\Delta \mathrm{E}_{\mathrm{it}}$} \\
\hline & & Coefficient & Standard error \\
\hline \multirow{6}{*}{ (1) Education Groups } & No schooling & -0.321 & $(0.34)$ \\
\hline & Primary & $-0.669 * *$ & $(0.251)$ \\
\hline & Lower secondary & $-0.578 * *$ & $(0.217)$ \\
\hline & Upper secondary & -0.223 & $(0.154)$ \\
\hline & $\begin{array}{l}\text { Matriculation and } \\
\text { non-degree }\end{array}$ & -0.192 & $(0.201)$ \\
\hline & College and above & -0.386 & $(0.254)$ \\
\hline \multirow{2}{*}{ (2) Gender } & Male & $-0.464 * * *$ & $(0.167)$ \\
\hline & Female & -0.533 & $(0.365)$ \\
\hline
\end{tabular}

Note: We have used weighted least squares with weights based on the industry employment share. In addition, we have also controlled for industry and year fixed effects. Robust standard errors are in parentheses. The significance levels: * significant at $10 \%$; * significant at 5\%; $* *$ significant at $1 \%$. 
Table 9. Industry-Occupation Mix (Dependent variable: average age of workers in the relevant cell)
(1)
(2)
(3)
(4)
(5)
(6)

Dependent

$\Delta \mathrm{O}_{\mathrm{j} t}$

Age $\left(\mathrm{O}_{\mathrm{j}}\right.$

$-0.219 * * *$

$(0.075)$

Industry-occupation

cell $\Delta \mathrm{IO}_{\mathrm{ij} \mathrm{t}}$
$-0.383 * *$

(0.168)
$-0.334 * *$

$(0.156)$

$-0.105^{* * *}$

$-0.078 * * *$

(0.023)

(0.026)

Industry-occupation

cell dummies

Industry dummies

Occupation dummies

Year dummies

Observations
Yes

No

No

Yes

No

Yes

Yes

Yes

280

0.79

0.89
130

0.88

No

No

Yes

Yes

Yes

Yes

Yes

Yes

Yes

Yes

280

280

280

Note: Weighted least squares estimation is used with the weights based on the employment share of each cell. Robust standard errors are in parentheses. The significance levels: * significant at $10 \%$; ** significant at $5 \% ; * * *$ significant at $1 \%$. 
Appendix Table 1. Recoding the Industry Variables according to the Codebook of Census Data

\begin{tabular}{|c|c|c|c|c|c|c|}
\hline industry & 1976 & 1981 & 1986 & 1991 & 1996 & 2001 \\
\hline Agricultural Products & $110-116$ & $110-118$ & $11-16$ & 1 & 110 & 110 \\
\hline Marine Fishing \& Fishery Products & $120-127$ & $120-129$ & 17 & 2 & 120 & 120 \\
\hline Mining and Quarrying & $210-212$ & $210-212$ & 18 & 3 & 210 & 210 \\
\hline Food, Beverage and Tobacco Industries & $310-315$ & $310-315$ & 21 & 31 & 310 & 310 \\
\hline $\begin{array}{l}\text { Manufacturing of Wearing Apparel, Leather and } \\
\text { Textile Goods }\end{array}$ & $320-346$ & $320-346$ & $22-31$ & $32-34$ & 321 & 321 \\
\hline $\begin{array}{l}\text { Manufacturing of Wood and Cork Products, } \\
\text { Furniture and Fixtures }\end{array}$ & $350-351$ & $350-351$ & 32 & 35 & 330 & 330 \\
\hline $\begin{array}{l}\text { Manufacturing of Paper and Paper Products, } \\
\text { Printing, Publishing }\end{array}$ & $360-361$ & $360-361$ & 33 & 36 & 340 & 340 \\
\hline $\begin{array}{l}\text { Manufacturing of Chemical Products, Coal and } \\
\text { Plastic }\end{array}$ & $390-392$ & $390-393$ & 39 & $37,38,41,42$ & $350,360,390$ & $350,360,390$ \\
\hline Manufacturing of Basic Metal Industries & $370-376$ & $370-376$ & 34 & 39 & 370 & 370 \\
\hline $\begin{array}{l}\text { Manufacturing of Machinery, Equipments, Parts } \\
\text { and Components }\end{array}$ & $380-387$ & $380-387$ & $35-38$ & 40 & 381 & 381 \\
\hline Electricity, Gas and Water & $410-420$ & $410-420$ & 41 & 4 & 410 & 410 \\
\hline Construction & $510-512$ & $510-512$ & $51-52$ & 51 & $500-600$ & $500-600$ \\
\hline Wholesale & 610 & 610 & 61 & 61 & 610 & 610 \\
\hline Retail & $611-613$ & 611 & 62-64, & 62 & 620 & 620 \\
\hline Import / Export & $614-615$ & $612-613$ & 65 & 63 & 630 & 630 \\
\hline Restaurants and Hotels & $620-621$ & $620-622$ & $66-69$ & 64 & 650 & 650 \\
\hline Transport and Supporting Services & $710-716$ & $710-719$ & $71-76$ & 71 & 710 & 710 \\
\hline Storage & 720 & 720 & 77 & 72 & 720 & 720 \\
\hline
\end{tabular}




\begin{tabular}{|l|c|c|c|c|c|}
\hline Communications & 721 & 721 & 78 & 73 & 730 \\
\hline Banking, Finance, and Investment Companies & 810 & 810 & $81-82$ & 81 & 810 \\
\hline Insurance & 811 & 811 & 83 & 82 & 820 \\
\hline $\begin{array}{l}\text { Real Estate, Rental, Surveying, and } \\
\text { Miscellaneous Services }\end{array}$ & $812-821$ & $812-821$ & $84-85$ & 84 & 830 \\
\hline $\begin{array}{l}\text { Public, Sanitary, Education, Research, Health, } \\
\text { Business, and Related Services }\end{array}$ & $910-914$ & $910-917$ & $90-95$ & 91 & $910,920,930$ \\
\hline Motion Pictures and Entertainment Services & $920-923$ & $920-923$ & 96 & $910,920,930$ \\
\hline $\begin{array}{l}\text { Repair Services, Laundry and Miscellaneous } \\
\text { Personal Services }\end{array}$ & $930-935$ & $930-936$ & $97-98$ & 95 & 941 \\
\hline
\end{tabular}


Figure 1. Sectoral Shifts and the Age Structure of Workers

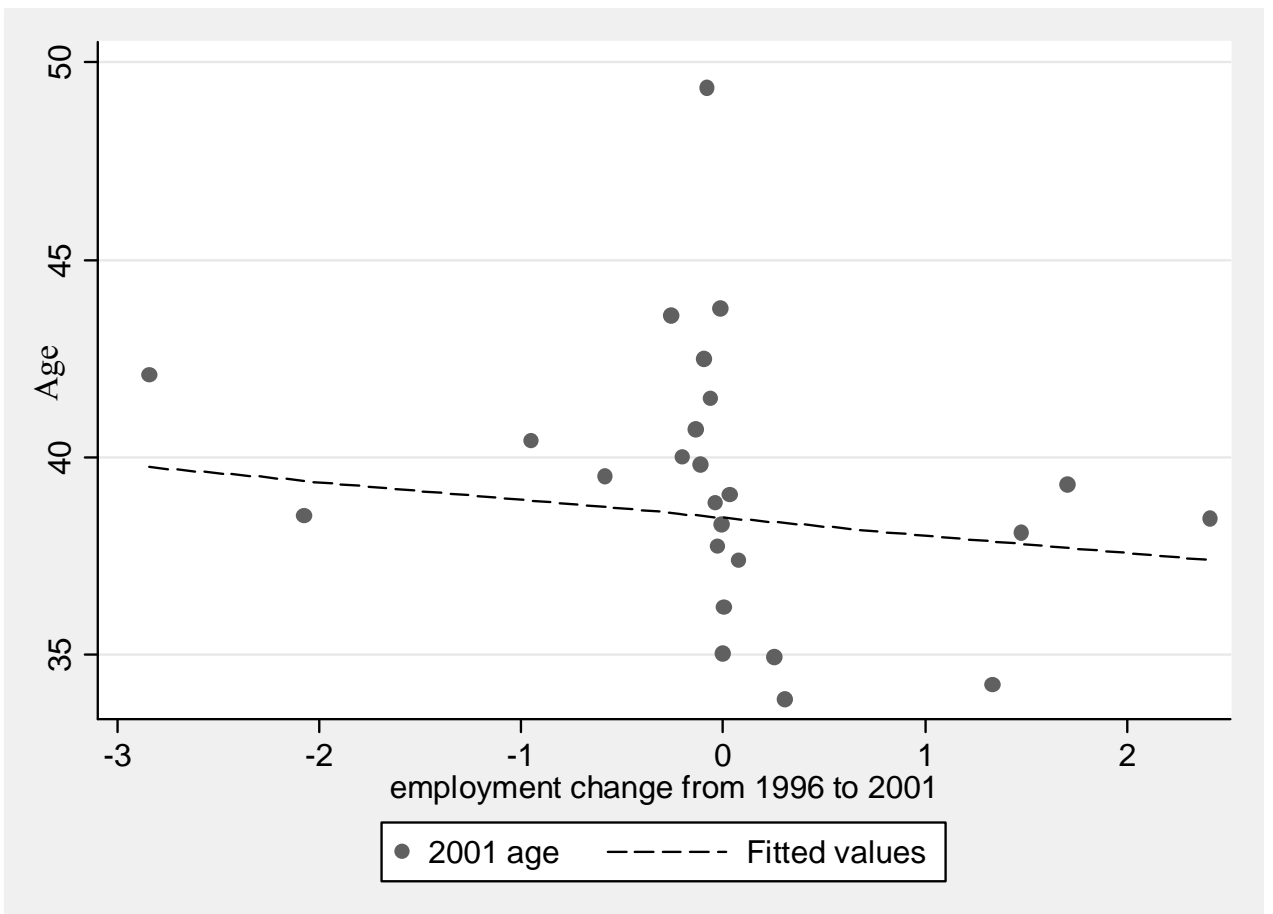


Figure 2. The Relationship between Industry Growth from 1981 to 1986 and the Consequent Unemployment Rate in 1986

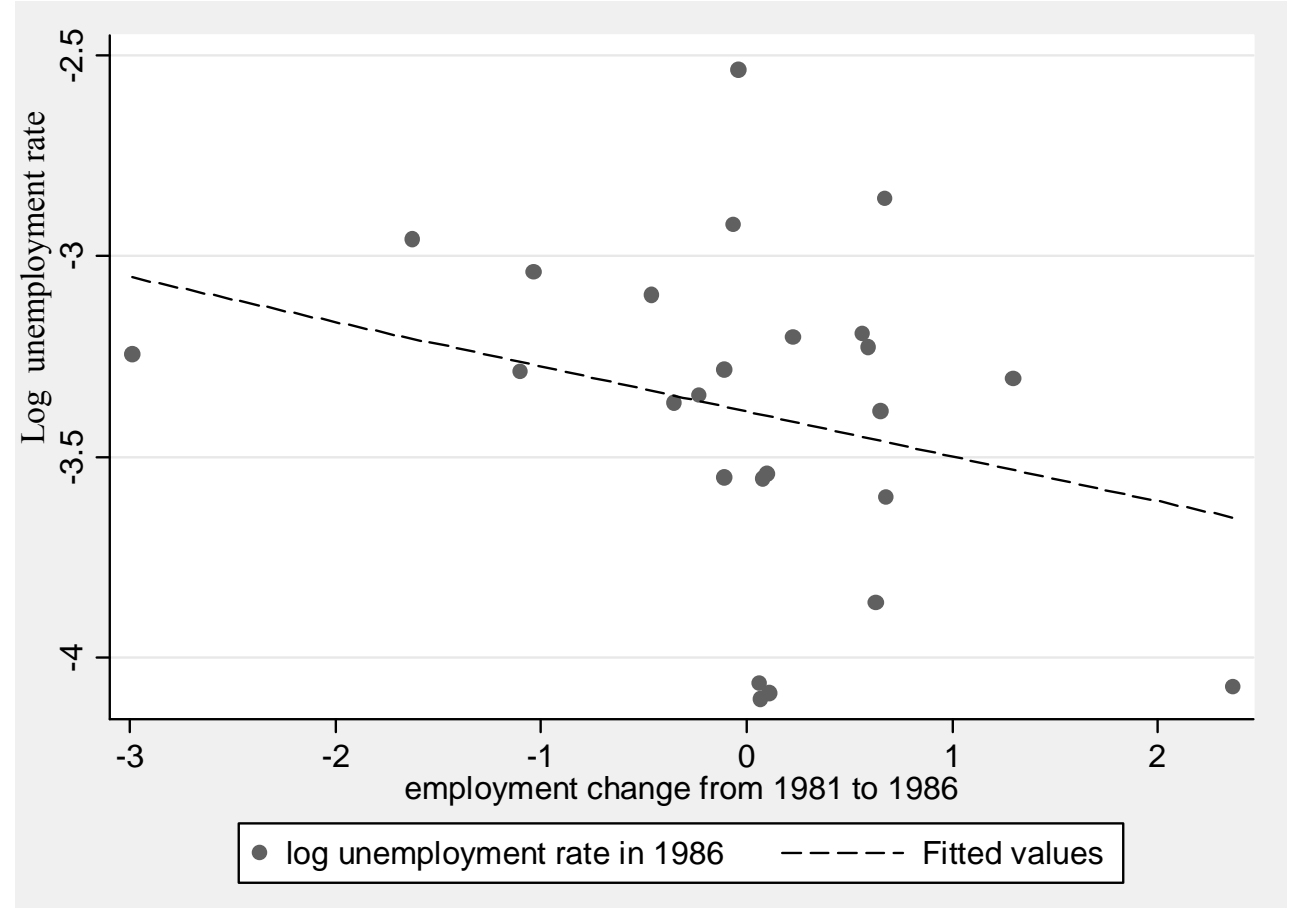

